\title{
Military buildings: from being abandoned to reuse
}

\author{
M. P. Gatti \& G. Cacciaguerra \\ Department of Civil, Environmental and Mechanical Engineering, \\ Trento University, Italy
}

\begin{abstract}
Recovery issues and typological and technological issues appear intrinsically connected on both conceptual and operational level and, as far as non-monumental "civilian" historic buildings are concerned, have been the subject of research for some time. However, publications on non-monumental "military" type historical buildings are less frequent.

This undoubtedly derives from the understandable reserve surrounding the construction of groups of building and other structures for the armed forces. These nevertheless represent a vast heritage to be re-introduced onto a circuit of "civilian" use, given the reconfiguration of defence models and consequent abandonment of a large number of structures.

The military complexes and single buildings constructed from the end of the 19th century are located in both natural settings and the urban fabric, where they now occupy central positions and therefore make an extremely attractive proposition for restoration and re-functionalization.

What documentary historical value in terms of typology and construction technique can be attributed to this particular type of military building?

What problems and strategies can be studied to re-introduce them correctly onto the circuit of use?

We will try and answer these questions by analysing the military structures in the city of Trento, built by first the Hapsburgs, then the Italian governments and now largely abandoned.

Keywords: recycle, military architecture, conservation, restoration.
\end{abstract}




\section{Introduction}

In 19th century Europe, wars, tensions and the constitution of modern states shifted borders repeatedly. It therefore became necessary to adapt military buildings to strategies that were being constantly modified as frontiers changed and weaponry developed.

The strength and habitability of defensive complexes were continuously improved by experimenting with new floor plans and wall elevations and by patenting new materials and technologies.

In a very short space of time, a complex and diversified system of military works came into being. Garrisons and fortifications (fortresses, troop stations, gun enclosures, etc.) were built in strategic areas that required protection against invasion and capture, along with a dense network of railways, cableways and roads, etc.

Construction continued without interruption; some works were abandoned without ever being used; others were converted immediately after completion; only a few actually served their original purpose.

In addition to defensive works as such, barracks also had to be provided in towns and cities to allow for the rotation of troops, who were unable to live for long periods under precarious conditions in isolated localities.

In urban areas, troops initially occupied existing buildings which were often monasteries confiscated from the religious orders during the Napoleonic period. Later, new buildings were constructed, including dormitories, military hospitals, and factories for manufacturing war materials, etc.

Medieval urban centres, until then enclosed by city walls, were gutted to create wide, straight roads more suitable for troop movements.

Towns and cities were connected with their surrounding areas by means of rapid rail links, reducing the isolation of many places and encouraging the circulation not only of people and goods, but ideas too.

As a period of great social, cultural and economic change, the 19th century saw the emergence of modern military architecture that permitted rational, efficient complexes to be constructed very rapidly.

The establishment of permanent garrisons necessitated the construction of dedicated buildings as quarters for troops who had, until then, been housed in temporary accommodation.

Within the war ministries, engineering corps and military academies of Europe's newly established nations, technical departments were set up to modernise military strategies, plan the distribution of new works and improve existing infrastructure.

To speed up the construction process, military architects began to standardise their designs to an extent unheard of in the civilian world. Specialist works were based not on trial and error, but on a quantitative and qualitative analysis of their intended functions. The most rational layouts and the best possible materials and technologies were soon identified. 
The main objectives in standardising the design and technology of military structures were to minimise construction costs and times and to eliminate known weaknesses in the face of ever more powerful artillery.

Military engineers were constantly ordered to devise new prototypes for field testing in one form or another.

The earliest standardised barracks were based on a monastery-like plan with a central courtyard, and proved both rational and functional for the purposes of the day. The need to increase capacity, however, led to the courtyard layout being abandoned in favour of large central spaces surrounded by purpose-built buildings.

These new barracks used the same materials and building techniques as fortified defences in order to minimise construction times, benefit from mass production processes and maximise structural strength.

Military academies and engineering corps were sworn to secrecy regarding the design of national defence works, but this did not prevent various European countries from adopting identical plans, materials and technologies. The result was a form of globalisation of military architecture.

From 1850 onwards, military structures with very similar architecture appeared all over Europe, with variations dictated only by the morphology of local terrain.

The historic value alone of the fortifications and barracks that were built throughout Europe makes them well worth conserving and even restoring according to today's cultural criteria.

In reality, however, they have been treated very differently in recent years. While military fortifications have sometimes benefited from conservation and restoration, perhaps because of their location within urban areas, barracks have not faired so well. The preferred course of action has been replacement, and individual buildings and entire complexes have been demolished as a result.

Most barracks built during the first half of the 19th century have seen some form of conservative restoration work, but demolition has become the norm for later constructions.

Different approaches to barracks and fortifications have been adopted not just in Italy but in many other European countries too.

We studied the barracks constructed by the Austro-Hungarian government in the garrison town of Trento with this in mind. Our intention was to highlight their historical value and to encourage proposals for their refurbishment and re-use, along with other abandoned structures, as an alternative to demolition.

This approach is becoming increasingly important when dealing with barracks located within the urban fabric, as the refurbishment of individual buildings and complete complexes is often the only course of action consistent with today's cultural and economic parameters.

The barracks we studied are located in Trento, a town on the Adige River considered by the Hapsburg government to be of strategic importance in blocking potential attacks from Italy.

In fewer than thirty years, a large number of structures were built around the town. These included: an infantry barracks, 1883-86; a military hospital, 189194; a light infantry and Bersaglieri barracks, 1894-96; a Tyrolean light infantry barracks, 1905-08; military baths; a swimming pool, two artillery ranges, a gallop, 
a munitions depot and a sappers barracks, 1914. (A horse-drawn artillery barracks and a mounted Bersaglieri barracks were also planned but never built.)

These structures dramatically increased the population of the walled town. With its native population of under 10,000 , Trento found itself home to over 30,000 troops. In short, it became a de facto garrison town.

Though Trento's military structures were similar to those built in most of Europe, the sheer scale of the works makes them a particularly valuable heritage and well worth conserving and restoring.

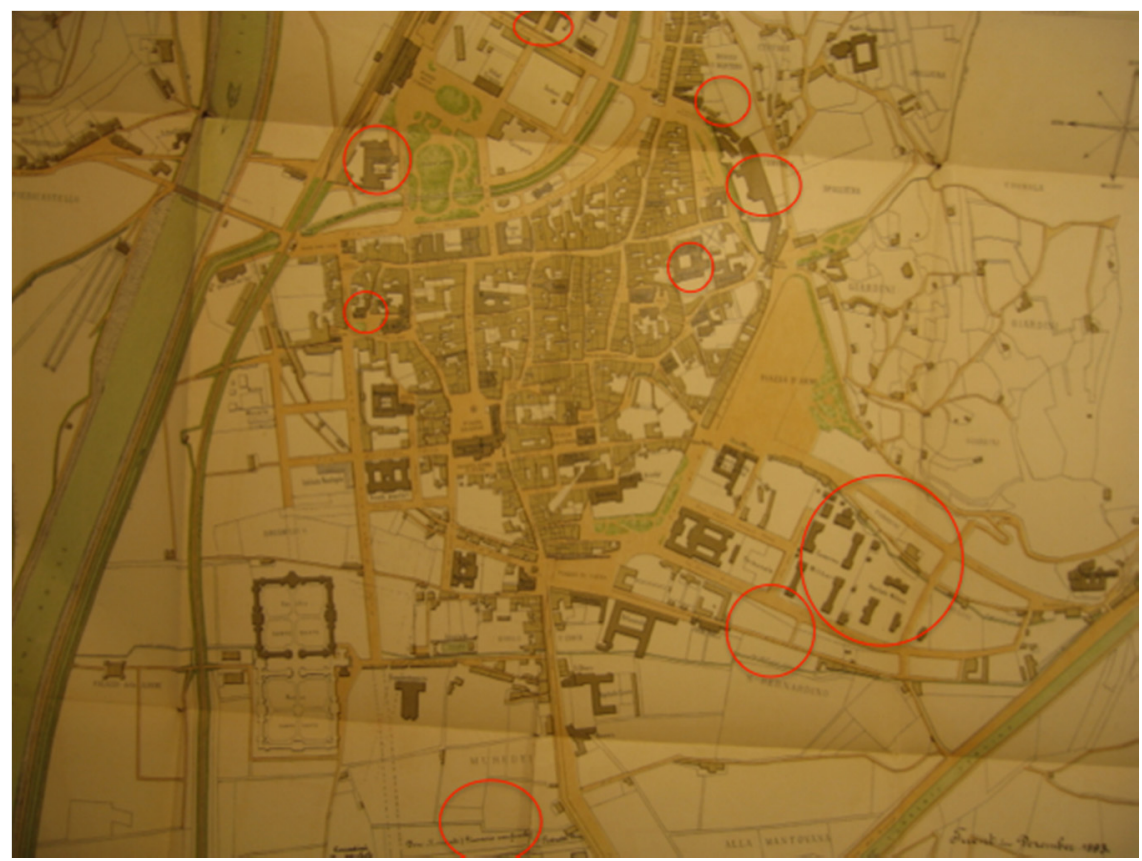

Figure 1: Plan of the City of Trento showing the areas occupied by the barracks, 1905.

\section{The characteristics of Trento's barracks}

Most of Trento's barracks were built outside the old town walls, which were being demolished at the time, in relatively undeveloped agricultural areas.

This choice of location was based partly on defensive considerations but largely on the need to avoid disturbing civilian life in the town centre.

Despite their rural locations, all the local barracks were well connected by main roads to the town and the surrounding countryside. In many cases, roads were laid down especially to serve the barracks.

In this period, the railway network assumed an extremely important role in military strategy, permitting the rapid movement of soldiers and armaments. Numerous lines were therefore constructed along the main valleys (the Brennero 
line for example) and minor valleys (Valsugana, Val di Non, etc.). In some cases, service lines were extended into the military enclosures themselves.

The barracks built in this period were generally characterised by a limited number of passages between the inside and outside worlds.

The land selected for their construction had to be prevalently flat as the drill and parade areas required even ground.

In many cases, construction as such was preceded by levelling work.

While a vehicular passage ran through the main entrance, connecting the interior to the urban road network, secondary entrances were usually pedestrian and accessed by steps.
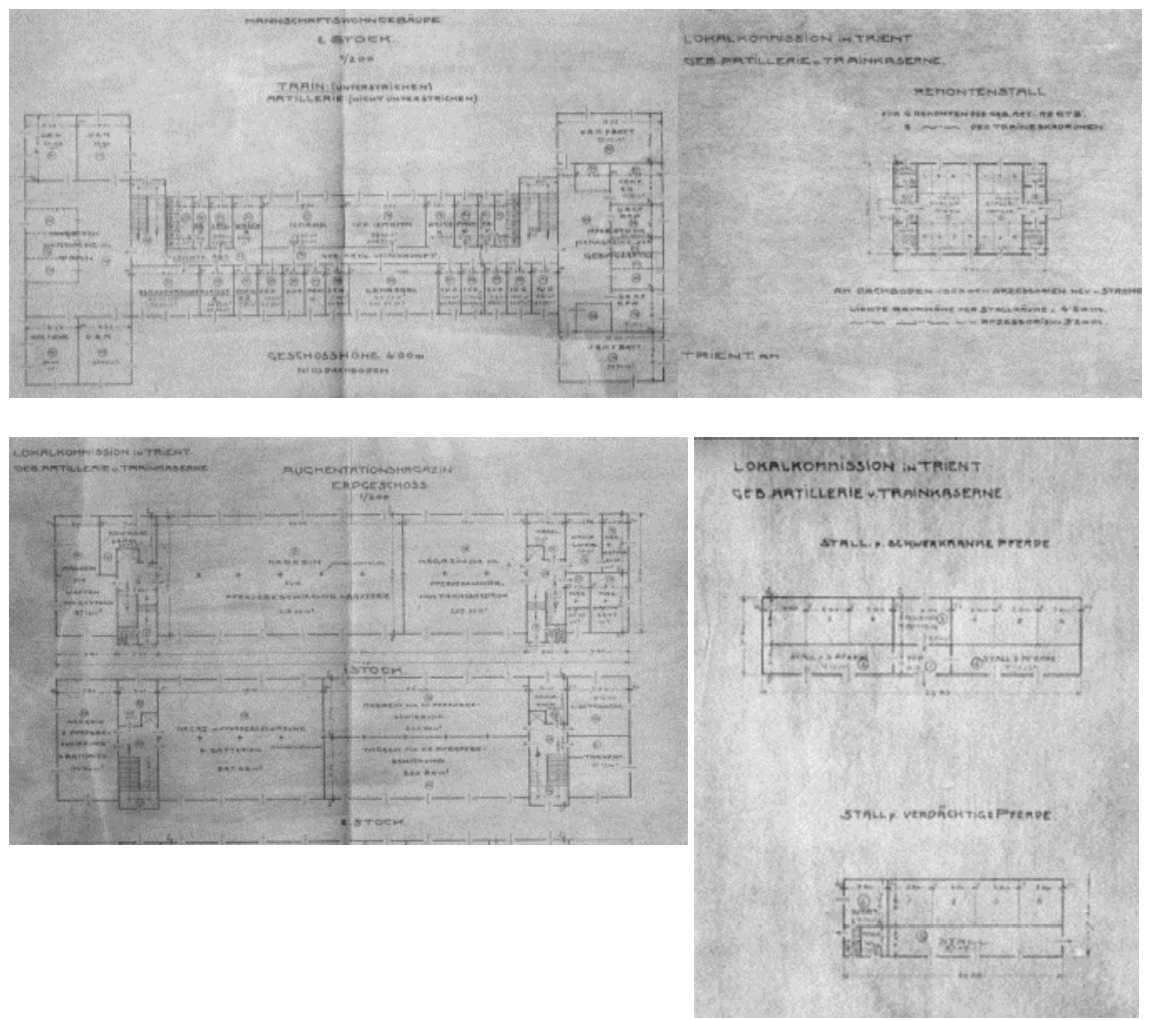

Figure 2: Line drawing produced by the engineering corps for use in design of the train-mounted artillery barracks.

Inside the barracks, nature was dominated by the needs of man. Gradients were eliminated; water (although indispensable) was removed by effective drainage; wind was blocked by careful positioning of buildings and trees; adequate heating was ensured by carefully calculated solar exposure. 
Whatever vegetation was permitted was used to conceal activities and to filter the sun's rays in order to optimise temperature inside the buildings in summer and winter alike. Evergreen trees were planted around the perimeter to restrict visibility from the outside, while deciduous trees were favoured for internal shade. Not even the choice and location of tree species were left to chance.

The barracks functioned as independent communities. Though civilian buildings eventually surrounded them, these remained totally unrelated to the layout of the military complex. A bird's eye view shows that most barrack paths ended at the walls. Only the main entrances were linked to the surrounding road network.

From the very beginning, barracks were laid out to resemble small towns. Wellestablished hierarchies led to the formation of primary and secondary spaces, squares, courtyards, roads and even gardens and parks. Outdoor spaces were surrounded by buildings that, though differing in plan, size and height, were stylistically homogeneous. The parade ground was always located well away from the perimeter, in a more or less central position, and was surrounded by the main buildings of the complex. Roads and paths led away from the parade ground to other more distant buildings.

Roads for vehicular traffic were kept distinct from pedestrian routes, but both were straight and of minimal length. Routes were not only surfaced but served by rainwater drainage systems as well.

The parade ground was always separate from the drill ground, and the relationship between these two spaces was similar to that between the church and town hall squares in a medieval city.

Another curious similarity was the presence of a clock on the main building, to mark out the soldier's day.

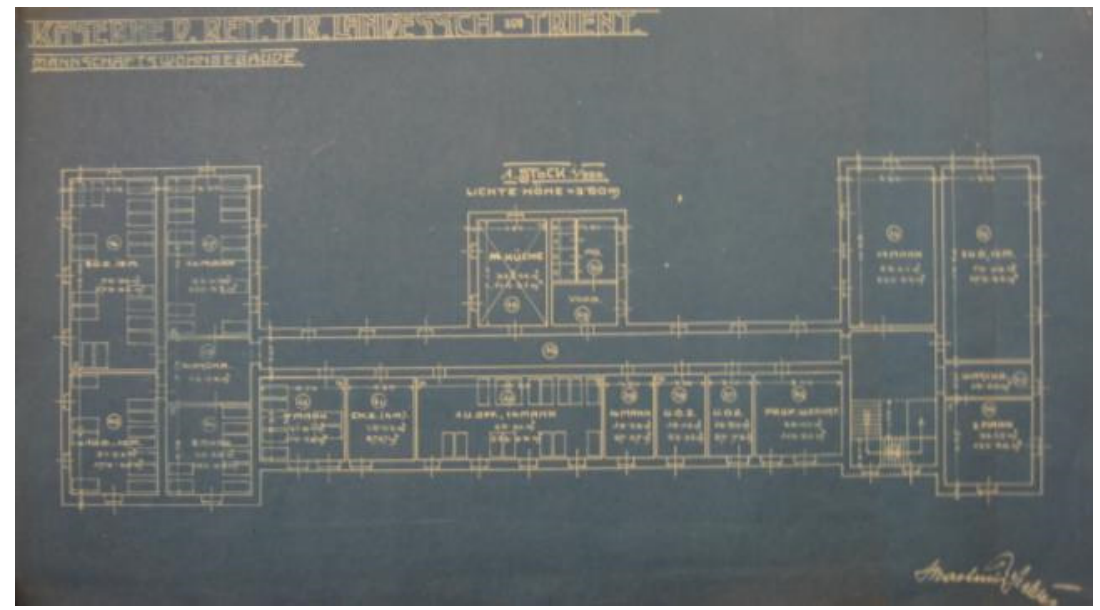

Figure 3: Plan of the first floor of the troop pavilion in the train-mounted artillery barracks. 
Security and functional criteria were paramount and internal space was arranged into blocks on the basis of defendability and autonomy. The most important buildings (the command building, the officers' and non-commissioned officers' blocks and the troop dormitories) were built around the main squares while the secondary buildings (stables, depots and stores) were built along internal roads.

Newly built barracks adopted one of two possible layouts, both based on the distribution of specialist buildings around a central space. While the buildings of the first layout formed a continuous wall, creating an enclosed courtyard, those of the second layout left open access between them.

The choice of layout depended mainly on the size of the enclosed space. The closed courtyard layout was adopted only for medium to small barracks. Open access layouts offered the advantage of permitting individual buildings (specialist or multi-functional) to be oriented freely in order to optimise exposure to the sun and wind. The buildings of both layouts were elementary structures of one $(<10$ $\mathrm{m})$ or two volumes $(>15 \mathrm{~m})$. Long corridors over 2 metres wide ran for their full length, generally on the side furthest away from the sun.

Building floor plans were based on the principle of symmetry. Many buildings adopted a three-part plan, with a central section and two wings. The central section housed the most important rooms while the wings housed minor functions and those that required most space. For example, in the dormitories, the officers' rooms were located in the central section while the sleeping areas for the common soldiers filled the wings.
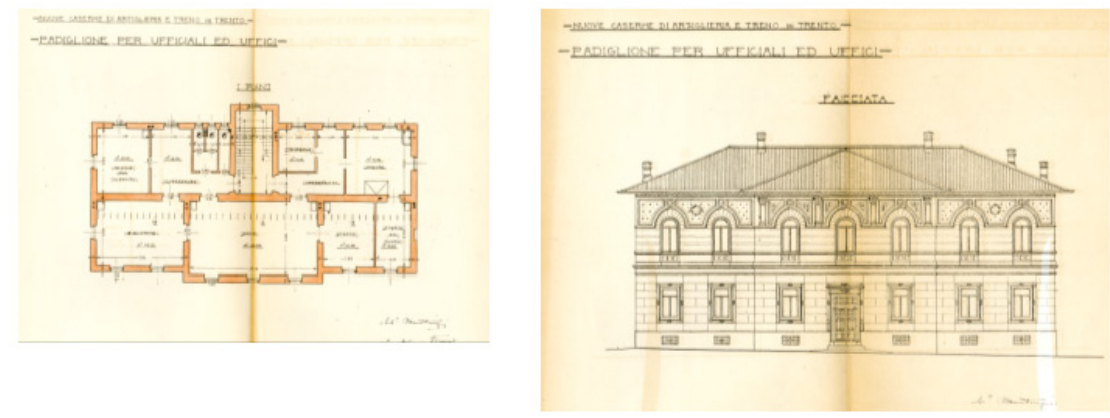

Figure 4: Plan and elevation of the officers' block and offices in the trainmounted artillery barracks.

The length of the building determined the number of staircases provided. Troop dormitories generally had two while one was sufficient for most other buildings. Stairwells were always positioned symmetrically and often formed a single unit with the toilets. Staircases could be double ramp or curved in design but were always wider than $1.50 \mathrm{~m}$ and comprised deep but low rise steps.

The main buildings in 19th century barracks extended over three or four storeys, always including a basement and attic. In accommodation blocks, the first floor was raised above ground level and accessed by wide steps. Good building practice 
at the time avoided placing living quarters at ground level even if the foundations were perfectly damp proof. The height of the floors was evident from the walls, which often had slight projections or recesses at the levels of the upper floors. On buildings with wings, the various outer walls were finished in different ways, the central façade being richly decorated; the wings being far more Spartan. The centre of the main façade was raised, or a tympanum was added to mark the entrance.

Barracks complexes consisted of the following buildings: a guard block, which could be a simple guard room, a military staff building, a non-commissioned officers' building, one or more troop dormitories, a mess with seating arranged by rank, a gym, a stores, armouries and stables.

Though a number of functions could be combined under one roof, the construction of general-purpose buildings was avoided as far as possible.
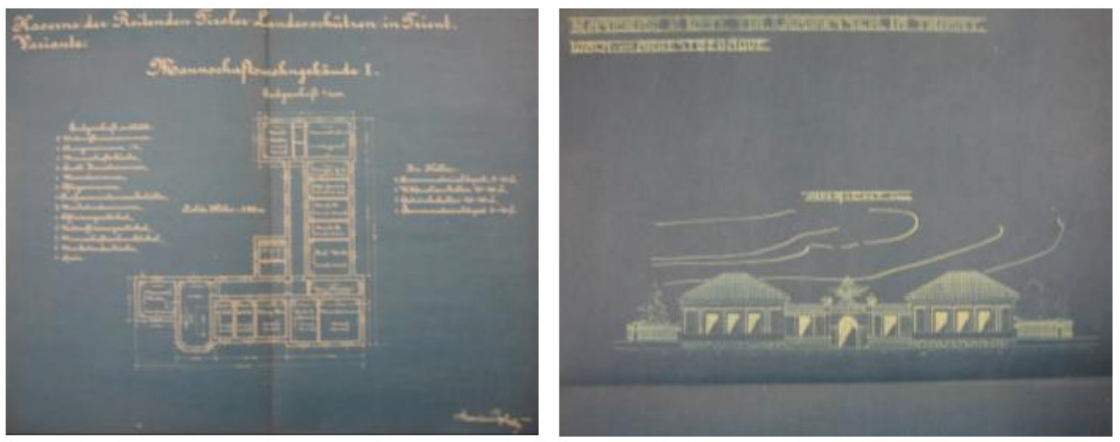

Figure 5: Plan of the ground floor of the troop pavilion in the train-mounted artillery barracks.

Constant experimentation led to individual functions becoming fully independent, as can be seen from the proliferation of single-purpose buildings. Even the design of troop dormitories followed this tendency, early open plan layouts giving way to separate rooms arranged along wide corridors.

The dimensions of barracks were common to all European nations: size was calculated on the basis of 20-25 $\mathrm{m}^{2}$ per man, depending on the branch of the armed forces, with outdoor areas and stables considered separately.

Between 4 and $5 \mathrm{~m}^{2}\left(20-25 \mathrm{~m}^{3}\right)$ of space per man was calculated for dormitory designs. This figure was again very similar across Europe: The British armed forces adopted 4.9 to $5.8 \mathrm{~m}^{2}$ per man, Russia 4.2 to $4.5 \mathrm{~m}^{2}$ and France 4 to $4.5 \mathrm{~m}^{2}$. In practice, dormitories accommodated up to $30 \mathrm{men}$, though the manuals recommended a figure of 10 to 12 . The depth of rooms depended on their length, but generally varied between 6.00 and $6.50 \mathrm{~m}$. Dormitory height also varied with capacity but was always more than $4 \mathrm{~m}$. Larger dormitories had rectangular windows whose size was determined according to a ratio of over 1:8 between glass and wall, corresponding to a window area of between 0.40 and $0.60 \mathrm{~m}^{2}$ per man. 
Special attention was paid to the design of communal areas, especially messes. The technical literature of the period recommended the construction of messes of 4.70-5.00x26.00 $\mathrm{m}$ to serve 150 soldiers. Messes could therefore be installed in single or double volume buildings, using a walk-through design in the former. The kitchen and storerooms for victuals and firewood were located alongside the dining area, preferably facing north for coolness.

The manuals also gave precise indications as to the size of the detention block $\left(0.04 \mathrm{~m}^{2}\right.$ per man, equivalent to one $2 \mathrm{~m}^{2}$ cell for every $\left.50 \mathrm{men}\right)$. Cells were generally single, $1.40 \times 1.90 \mathrm{~m}$ in size, and equipped with a ventilation flue and high window openings.

Specifications even covered the size of the storerooms, guard house and holding cell, laundry and ironing block and non-commissioned officers' quarters, etc..

The stables too were built to precise indications, with three different box sizes laid down $(52.50 \times 21.00 \mathrm{~m}, 47.50 \times 19.00 \mathrm{~m}$ and $38.00 \times 18.00 \mathrm{~m})$ and the possibility of adding a guard post at one end. Even the composition of the stable floors was specified. Soil should be excavated to a depth of about $50 \mathrm{~cm}$ and the resulting pit filled for the bottom two fifths with fine gravel and for the remaining three fifths with hard wood sawdust. Alternatively, the floor could be cobbled or cast in concrete and covered by a layer of sawdust (minimum $20 \mathrm{~cm}$ ). One latrine was to be provided for every 20 men.

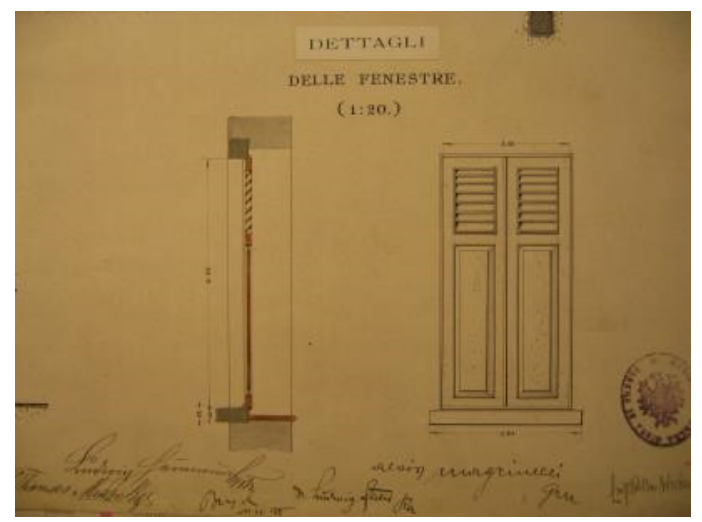

Figure 6: Detail of a window.

Plans required the construction of day latrines around the squares and night latrines in the dormitories, both connected to the public sewers or to a cesspool.

There were many similarities between barracks even in terms of construction techniques, with a large number of buildings completed in reinforced concrete. Continuous stone walls were rapidly replaced, initially with walls incorporating steel frames, then with reinforced concrete structures. Reinforced concrete soon became established in military architecture as a result of its characteristics of strength and resistance to fire. Tests conducted by engineering corps technical departments soon showed that there was room for improvement, however. Studies 
were therefore encouraged to develop new applications, optimise composition and maximise the bond between steel reinforcement and concrete agglomerate to create a truly monolithic material. As a result, concrete found new uses in floors too: wood beams were replaced with reinforced concrete slabs or combinations of brick and cement. Specialist studies focused on internal and external door and window frames, incentivating the industrial production of concrete and steel frames in addition to traditional wood types.

From the very start, military complexes benefited from efficient water and heating, and later electrical systems, pioneering techniques which would later be applied to civilian architecture.

\section{Conclusions}

Like many other buildings of the period, 19th century barracks were the fruit of an approach to architecture based on a culture of enlightenment. Their layout, design and construction was accurately predefined in order to permit the rapid completion of a large number of units.

Though modern in conception, the barracks of the period also made effective use of older architectural principles, reinterpreting and updating them to apply to complexes of inter-related but monofunctional buildings.

Our study of the Trento barracks has revealed both the potential and the limits of any hypothetical adaptation. Similar studies of barracks in other towns would presumably produce similar findings.

One good reason for recovering these structures is that, though they lie outside the 19th century town, they now occupy relatively central and therefore extremely attractive positions. The buildings themselves are also arranged in a hierarchical way that makes them easy to adapt for civilian purposes. The complexes as a whole also benefit from far larger open spaces than the suburbia constructed after the Second World War.

The barracks' internal road system could easily be connected to the external road network to allow them to accommodate local facilities that have never been built due to lack of space. This would clearly help improve the infrastructure of our modern cities, all too often developed in haste and without due consideration for the future.

Parade grounds could provide excellent locations for meetings, entertainment, socialisation and other public functions. Green areas and sports fields could be developed in the larger barracks. In many cases they would not even have to be built as they were already part of the 19th century plan.

In addition to the layout of the complex as a whole, the simplicity and size of the individual buildings is another great advantage. Their versatility makes them ideal for a wide variety of uses. Many barracks buildings could be adapted to suit a range of purposes with only a minimum of work.

The functional versatility of Trento's barracks has already been demonstrated: when the region became part of Italy, a number of military buildings were converted for use as schools and housing. 
Though they were designed by anonymous military engineers, these disused military barracks thoroughly deserve re-assessment of their architectural qualities. Further study is required to evaluate all aspects of these complexes and identify their full potential for re-use.

After so many proposals for complete demolition, the time has come to review the possibility of recovering all, or at least some of these valuable buildings.

\section{References}

[1] Gatti, M. P., La città militare di Trento: costruzione, dismissione, riuso, in Storelli, F., Architetture militari e città, ed. Palombi Editori, Roma, pp. 8-83, 2012.

[2] Cacciaguerra, G., Gatti, M. P., Military structures of Trento: Conserving and restoring value, Save Heritage: Safeguard of architectural visual, environmentall Heritage, ed. La scuola di Pitagora editrice, Norcone, Benevento, 2011.

[3] Cacciaguerra, G., Gatti, M. P., The First Reinforced Concrete Structures in Urban Renewal in an Italian Provincial City, Advanced materials research, vol. 133-134, pp. 187-192, 2010.

[4] Cacciaguerra, G., Gatti, M. P., The modernity exhibited by the building technologies adopted for nineteenth century trentine fortresses. IAHS World Congress on Housing 2010, Santander, 26-29 October, 2010, pp. 1-9, 2010.

[5] Cacciaguerra, G., Gatti, M. P., Military architecture a pool of installations to preserve or demolish? Proceedings of the Third International Congress on Construction History. Cottbus, Germany, 20th-24th May 2008, pp.275-281, Neunplus, Berlin, 2008. 